\title{
Climate Suitability for Magnaporthe oryzae Triticum Pathotype in the United States
}

Christian D. Cruz, Department of Plant Pathology, Kansas State University, Manhattan 66506; Roger D. Magarey and David N. Christie, Center for IPM, North Carolina State University, Raleigh 27606; Glenn A. Fowler, United States Department of Agriculture-Animal and Plant Health Inspection Service, Plant Protection and Quarantine, Center for Plant Health Science and Technology, Plant Epidemiology and Risk Analysis Laboratory, Raleigh, NC 27606; Jose M. Fernandes, Embrapa Trigo, CEP 99001-970, Passo Fundo, RS, Brazil; and William W. Bockus, Barbara Valent, and James P. Stack, Department of Plant Pathology, Kansas State University

\begin{abstract}
Cruz, C. D., Magarey, R. D., Christie, D. N., Fowler, G. A., Fernandes, J. M., Bockus, W. W., Valent, B., and Stack, J. P. 2016. Climate suitability for Magnaporthe oryzae Triticum pathotype in the United States. Plant Dis. 100:1979-1987.

Wheat blast, caused by the Triticum pathotype of Magnaporthe oryzae, is an emerging disease considered to be a limiting factor to wheat production in various countries. Given the importance of wheat blast as a high-consequence plant disease, weather-based infection models were used to estimate the probabilities of $M$. oryzae Triticum establishment and wheat blast outbreaks in the United States. The models identified significant disease risk in some areas. With the threshold levels used, the models predicted that the climate was adequate for maintaining $M$. oryzae

Triticum populations in $40 \%$ of winter wheat production areas of the United States. Disease outbreak threshold levels were only reached in $25 \%$ of the country. In Louisiana, Mississippi, and Florida, the probability of years suitable for outbreaks was greater than $70 \%$. The models generated in this study should provide the foundation for more advanced models in the future, and the results reported could be used to prioritize research efforts regarding the biology of $M$. oryzae Triticum and the epidemiology of the wheat blast disease.
\end{abstract}

Wheat blast, caused by the Triticum pathotype of Magnaporthe oryzae (synonym Pyricularia oryzae Triticum pathotype), emerged as a new disease in northern Paraná, Brazil, in 1985 (Igarashi et al. 1986). On wheat, blast is primarily regarded as a head disease (Igarashi 1990). Depending on the point and time of infection, symptoms on heads can vary from small elliptic lesions to partial or total spike bleaching, sterility, and empty spikes (Igarashi 1990; Igarashi et al. 1986). Despite reports (Aucique Perez et al. 2014; Igarashi 1990; Rios et al. 2013) describing blast lesions on wheat leaves, the prevalence of leaf lesions on severely affected commercial fields is currently disputed (Cruz et al. 2015). However, M. oryzae has been found to cause leaf lesions on wheat at the vegetative stage, and also to sporulate on wheat basal leaves of adult plants (Cruz et al. 2015).

\section{Corresponding author: J. P. Stack; E-mail: jstack@ksu.edu}

The United States Department of Agriculture (USDA) prohibits discrimination in all its programs and activities on the basis of race, color, national origin, age, disability, and where applicable, sex, marital status, familial status, parental status, religion, sexual orientation, genetic information, political beliefs, reprisal, or because all or part of an individual's income is derived from any public assistance program. (Not all prohibited bases apply to all programs.) Persons with disabilities who require alternative means for communication of program information (Braille, large print, audiotape, etc.) should contact USDA's TARGET Center at (202) 720-2600 (voice and TDD). To file a complaint of discrimination, write to USDA, Director, Office of Civil Rights, 1400 Independence Avenue, S.W., Washington, D.C. 20250-9410, or call (800) 795-3272 (voice) or (202) 720-6382 (TDD). USDA is an equal opportunity provider and employer. Mention of trade names or commercial products in this publication is solely for the purpose of providing specific information and does not imply recommendation or endorsement by the U.S. Department of Agriculture.

*The $\boldsymbol{e}$-Xtra logo stands for "electronic extra" and indicates that two supplementary figures are published online.

Accepted for publication 24 May 2016

http://dx.doi.org/10.1094/PDIS-09-15-1006-RE

(C) 2016 The American Phytopathological Society
Brazil produces spring wheat in the central, south-central, and southern climatic regions (Kochhann 1987). The top producing states are Paraná and Rio Grande do Sul (CONAB 2015; Kochhann 1987), which account for approximately $90 \%$ of the national annual wheat production (CONAB 2015). Paraná and Rio Grande do Sul are located in the south-central and southern wheat-growing regions of Brazil (Kochhann 1987) and are considered natural habitats for M. oryzae Triticum. Historically, wheat blast outbreaks have sporadically occurred and caused the greatest yield and economic losses in northern and western Paraná (Alves and Fernandes 2006; Antunes da Cruz 2008; Igarashi 1988; Lima 2004). In the southern wheat-growing region, temperatures during the winter are low and may fall below freezing during the growing season (Kochhann 1987). In Rio Grande do Sul, wheat blast can occur in favorable microclimates without causing significant damage (Antunes 2014) and its incidence has been historically very low, possibly due to unsuitable temperatures for disease development (Antunes 2014; Lima 2004).

The United States produces wheat in almost all of the 48 contiguous states. Climate, regional differences, and wheat classes influence wheat production and practices in the United States (Vocke and Ali 2013). Two classes of U.S. wheat include winter and spring wheat (Vocke and Ali 2013). Winter wheat varieties, which represent 70 to $80 \%$ of total U.S. wheat production, are sown in the fall to germinate and become established before entering a dormant phase during the winter (Vocke and Ali 2013). Winter wheat is grown primarily in the Great Plains, the eastern states, and the states along the Mississippi River (Vocke and Ali 2013). Spring wheat varieties are planted in the spring and harvested in late summer or fall (Vocke and Ali 2013). Spring wheat is grown in the Northern Plains, where harsh winters would kill winter wheat during dormancy (Vocke and Ali 2013).

Two phylogenetic relatives of M. oryzae Triticum, M. oryzae Lolium and $M$. oryzae Oryza, are already established in the United States (Farman 2002; Harmon and Latin 2003; Latin and Harmon 2004; Marchetti et al. 1976). M. oryzae Lolium and Oryza pathotypes are the causal agents of gray leaf spot of perennial ryegrass and rice blast, respectively, two diseases that have occurred at epidemic levels in the United States (Harmon and Latin 2003; Marchetti et al. 1976; Uddin 
et al. 2003a, b). The environmental conditions that support disease development are similar among the $M$. oryzae Oryza, Lolium, and Triticum relatives (Anderson et al. 1947; de Andrade Cardoso et al. 2008; Uddin et al. 2003a). However, in temperate regions, populations of the M. oryzae Lolium and Oryza pathotypes are reduced by winter conditions (Harmon and Latin 2003; Kapoor and Singh 1977; Latin and Harmon 2004). For instance, wintertime freezing temperatures limit the survival of the $M$. oryzae Lolium pathotype in some U.S. areas (Harmon and Latin 2003, 2005; Latin and Harmon 2004).

To date, South American strains of M. oryzae Triticum have not been detected in the United States. However, as a prelude to its possible introduction, models were required for preliminary risk evaluation of climate suitability for $M$. oryzae Triticum establishment and wheat blast outbreak. Climate suitability mapping is a type of predictive mapping that can identify areas where the climatic conditions may be suitable for a pathogen to persist from one season to another (i.e., establishment) (IPPC 2008; Yang 2003, 2006) and for disease development sufficient to cause economic loss or an epidemic greater than what would normally be expected (i.e., outbreak) (McMichael et al. 2003; Yang 2006). Climate suitability maps can be developed using models relying on biological information derived from controlled experiments or from the observed geographic distribution of the pest (Fowler and Takeuchi 2012; Venette et al. 2010). As a result, this research sought to compile epidemiological information about wheat blast in an effort to predict where $M$. oryzae Triticum might establish in the United States and where it might cause significant losses.

\section{Materials and Methods}

In this study, specific combinations of environmental conditions for M. oryzae Triticum inoculum buildup prior to wheat heading, infection at the heading stage, and overwintering survival of $M$. oryzae Triticum inoculum were deemed useful to predicting the estimated likelihood of M. oryzae Triticum establishment and wheat blast outbreak (Fig. 1). The overlying assumption was that the establishment and outbreak processes were driven by the same components and equations but with different thresholds. Establishment was defined as environmental conditions that allowed the pathogen to persist from one season to another. Outbreaks were defined as environmental conditions that allowed for epidemics that caused commercial losses in wheat fields in specific years and locations. The wheat blast disease cycle was separated into the following three components: (i) M. oryzae Triticum inoculum buildup prior to heading (IB), (ii) $M$. oryzae Triticum infection during the heading stage (IH), and (iii) overwintering survival of $M$. oryzae Triticum inoculum during the growing season (OS) (Fig. 1). Components IB and IH were selected based on the premise that the wheat blast disease results from inoculum buildup prior to heading and infection of heads across fields. Conidia were considered to be the primary structures that $M$. oryzae Triticum uses for spread and infection at the rachis level. Stage OS was selected based on evidence that shows that phylogenetic relatives of M. oryzae Triticum are reduced by winter conditions in temperate regions (Harmon and Latin 2003; Kapoor and Singh 1977; Latin and Harmon 2004). The IB and IH components were based on an infection model (i.e., multiple infection cycles lead to buildup of inoculum; Magarey et al. 2005), as described below. In epidemiological research in Bolivia using a highly susceptible cultivar, infection of leaves led to spore production, new leaf infections, and new spores that served as a potential source of $M$. oryzae Triticum inoculum (C. D. Cruz and J. Kiyuna, unpublished). Stage OS was defined by survival of inoculum and estimated from minimum daily temperatures $\leq 0^{\circ} \mathrm{C}$ extrapolated and adapted from published research (Harmon and Latin 2003; Latin and Harmon 2004).

Probabilities for M. oryzae Triticum establishment were estimated and spatially explicit cumulative risk maps developed using the formula $P_{e}=I B_{w} \times I H_{x} \times O S$, where $\mathrm{P}_{\mathrm{e}}$ was the probability of $M$. oryzae Triticum establishment in the contiguous United States; $\mathrm{IB}_{\mathrm{w}}$ was the probability of years suitable for inoculum buildup prior to heading, with a $w$ threshold for inoculum buildup prior to heading associated with M. oryzae Triticum establishment; $\mathrm{IH}_{\mathrm{x}}$ was the probability of years suitable for infection at the heading stage, with an $x$ threshold for infection at the heading stage associated with M. oryzae Triticum establishment; and OS corresponded to the probability of years suitable for M. oryzae Triticum inoculum overwintering based on the number of days below freezing. The equation used to predict wheat blast outbreaks was $P_{o}=I B_{w} \times I H_{x} \times O S$, with $w$ and $x$ thresholds associated with wheat blast outbreaks (explained below).

Our climate-based mechanistic approach used the North Carolina State University/Animal and Plant Health Inspection Service Plant Pest

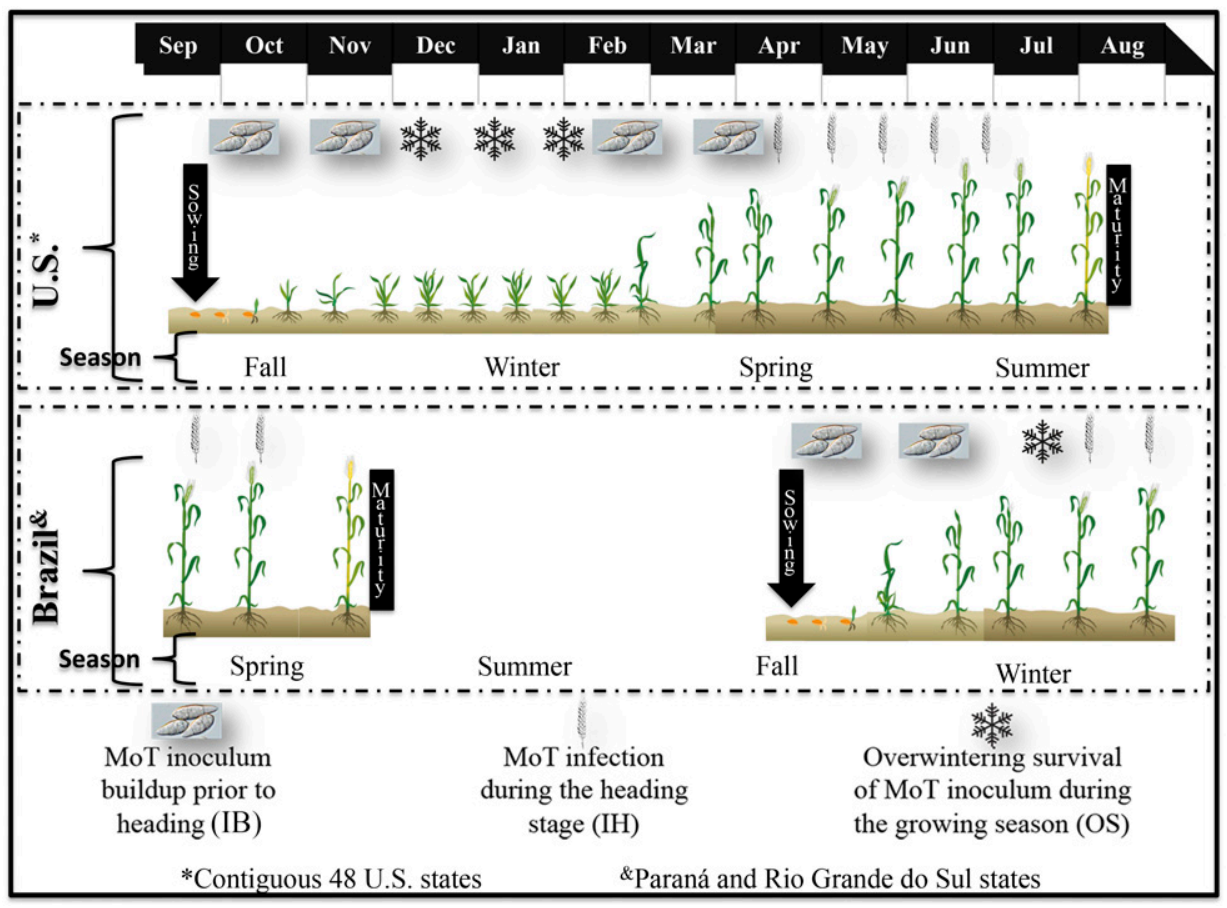

Fig. 1. Phenological crop calendar of winter wheat in the United States (U.S.) and spring wheat in Brazil. The wheat blast disease cycle was separated into three components for modeling purposes: Magnaporthe oryzae Triticum inoculum buildup, infection during heading, and overwintering survival of M. oryzae Triticum inoculum. Differences in agroecosystems existed between the United States and Brazil. 
Forecast (NAPPFAST) web-based modeling system (Magarey et al. 2005, 2007, 2015). NAPPFAST linked georeferenced climatological data with biological templates for modeling. The biological templates in NAPPFAST included a generic infection model based on a temperature-moisture response function (TMRF) that used cardinal temperatures (minimum, optimal, and maximum temperatures $=\mathrm{T}_{\min }$, $\mathrm{T}_{\text {opt }}$, and $\mathrm{T}_{\max }$, respectively), wetness requirements for infection (minimum and maximum wetness $=\mathrm{W}_{\min }$ and $\mathrm{W}_{\max }$, respectively), and a moisture requirement for splash dispersal (Magarey et al. 2005, 2007). The NAPPFAST TMRF algorithm is $\mathrm{I}=\mathrm{W} \times f(\mathrm{~T}) / \mathrm{W}_{\min }$ (Magarey and Sutton 2007; Magarey et al. 2005), where I = infection score, $\mathrm{W}=$ wetness duration hours, $f(\mathrm{~T})=$ temperature response function, $\mathrm{W}_{\min }=$ minimum wetness duration requirement, and $\mathrm{W}_{\max }=$ maximum wetness duration requirement (Magarey and Sutton 2007). In this study, $M$. oryzae Triticum's infection score has a maximum value of 2.0 equivalent to a value of $\mathrm{W}_{\max } / \mathrm{W}_{\min }$. The model also includes an optional precipitation requirement to account for the splash dispersal of spores. If precipitation on a given day does not meet the splash requirement, then the infection score for that day is zero. Infection values for components IB and IH included daily temperatures $\left(\mathrm{T}_{\min }=10^{\circ} \mathrm{C}, \mathrm{T}_{\mathrm{opt}}=27.5^{\circ} \mathrm{C}\right.$, and $\mathrm{T}_{\max }=$ $\left.32^{\circ} \mathrm{C}\right)$, leaf wetness duration $\left(\mathrm{W}_{\min }=12 \mathrm{~h}\right.$ and $\left.\mathrm{W}_{\max }=24 \mathrm{~h}\right)$, and precipitation for splash dispersal ( $>2 \mathrm{~mm})$. Cardinal temperatures, wetness, and precipitation were obtained from published research (Alves and Fernandes 2006; Anderson et al. 1947; de Andrade Cardoso et al. 2008; Moss and Trevathan 1987). The NAPPFAST system processed daily weather data into infection potential using the TMRF function. Its built-in accumulate function was used to determine the number of days of a given event (i.e., infection or survival; Magarey et al. 2007). To create spatially explicit cumulative risk maps, each grid cell was assigned a daily value for infection score between 0 (unfavorable) and 2 (favorable). Values were accumulated over time to obtain the infection score for components IB and $\mathrm{IH}$, and days with temperatures $\leq 0^{\circ} \mathrm{C}$ for component OS. NAPPFAST generated three types of risk maps based on a specific model and specified dates: (i) average history maps showing the

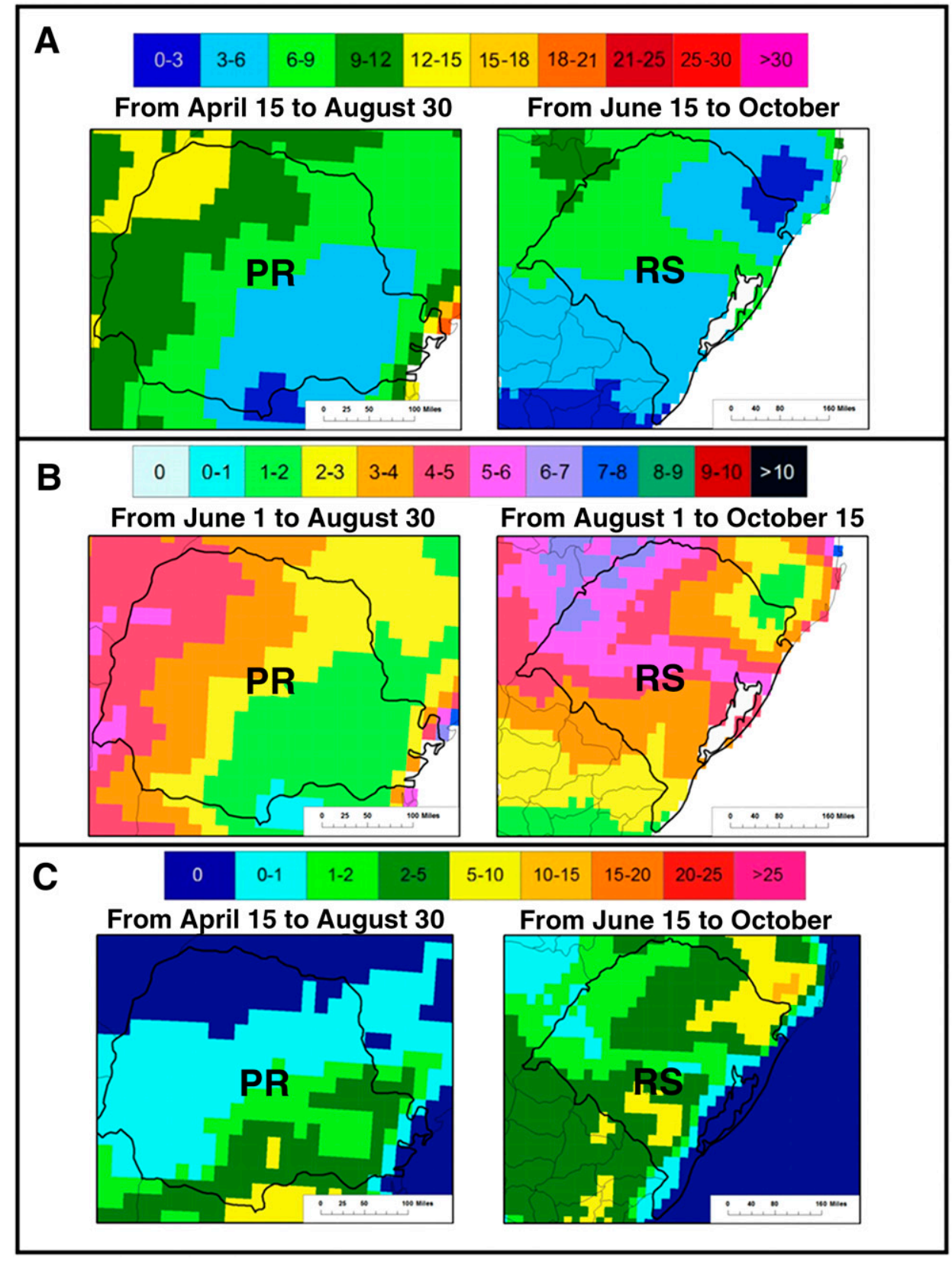

Fig. 2. Model predictions for wheat blast in Paraná (PR) and Rio Grande do Sul (RS) Brazil based on 10 year of climate data. Maps show the $\mathbf{A}$, average infection score values during the growing season; $\mathbf{B}$, infection score during the heading stage; and $\mathbf{C}$, days with temperatures $\leq 0^{\circ} \mathrm{C}$ during the growing season. Infection scores were based on a generic infection model that used a temperature-moisture response function. 
average accumulated value based on 10 years of weather data, (ii) probability maps showing the frequency of suitable years above or below a specific threshold, and (iii) accumulated values for a specific year (Magarey et al. 2015).

To select thresholds for the model, we developed climate suitability maps for Paraná and Rio Grande do Sul showing the average infection score during the growing season, infection score during heading, and days with temperatures $\leq 0^{\circ} \mathrm{C}$ during the growing season. Maps were constructed using the built-in accumulate function from NAPPFAST to display the number of accumulated events, from which thresholds were selected empirically. NAPPFAST generated these risk maps at a resolution of $38 \mathrm{~km}\left(1,444 \mathrm{~km}^{2}\right)$ (Magarey et al. 2011; Saha et al. 2006). Regional growing season dates for Paraná and Rio Grande do Sul were 15 April to 30 August and 15 June to 15 October, respectively (Junges and Fontana 2009). Regional heading dates for Paraná and Rio Grande do Sul were 1 June to 30 August and 1 August to 15 October, respectively (Junges and Fontana 2009). Maps were based on the average values obtained from 10 years of National Centers for Environmental Prediction Climate Forecast System Reanalysis climate data for Paraná and Rio Grande do Sul. M. oryzae Triticum is established in Paraná and Rio Grande do Sul but wheat blast outbreaks have historically occurred in northern and western Paraná. This knowledge provided an opportunity to empirically select thresholds associated with M. oryzae Triticum establishment or wheat blast outbreaks. To discern quantitative differences between wheat blast outbreaks in northern and western Paraná and M. oryzae Triticum establishment in Rio Grande do Sul in relation to components IB and IH, we compared and contrasted the average accumulated infection scores (Fig. 2A and B). We tested these thresholds by creating model outputs using weather data for individual years. Two types of model outputs were calculated. First, accumulated infection maps for individual years were created for years where observation data were available. Second, probability maps were created by calculating the frequency of years that a grid cell was above the derived thresholds for outbreaks and establishment. The resulting model outputs were compared with historical observations of years in recent history when wheat blast outbreaks occurred in northern and western Paraná in 1987, 2004, and 2009 (Alves and Fernandes 2006; Antunes da Cruz 2008; Igarashi 1988; Lima 2004; Torres et al. 2009) or did not occur during 2003,

Table 1. Categorization of U.S. states into three tiers based upon wheat development

\begin{tabular}{|c|c|c|c|c|}
\hline \multirow[b]{2}{*}{ Tier } & \multirow[b]{2}{*}{ States } & \multirow{2}{*}{$\begin{array}{c}\text { Winter } \\
\text { end }^{\mathbf{b}}\end{array}$} & \multicolumn{2}{|c|}{ Heading perioda } \\
\hline & & & Begin & Feekes \\
\hline$\overline{1}$ & $\begin{array}{l}\text { Arkansas, Alabama, Arizona, } \\
\text { California, Florida, Georgia, } \\
\text { Louisiana, Mississippi, } \\
\text { Oklahoma, South Carolina, } \\
\text { Texas, North Carolina }\end{array}$ & 5 February & 5 April & 20 May \\
\hline 2 & $\begin{array}{l}\text { Delaware, Illinois, Kansas, } \\
\text { Kentucky, Maryland, Missouri, } \\
\text { New Jersey, New Mexico, } \\
\text { Tennessee, Virginia }\end{array}$ & 3 March & 3 May & 9 June \\
\hline 3 & $\begin{array}{l}\text { Colorado, Connecticut, Idaho, } \\
\text { Indiana, Iowa, Maine, } \\
\text { Massachusetts, Michigan, } \\
\text { Minnesota, Montana, Nevada, } \\
\text { New Hampshire, New York, } \\
\text { North Dakota, Ohio, Oregon, } \\
\text { Rhode Island, South Dakota, } \\
\text { Utah, Vermont, Washington, } \\
\text { West Virginia, Wisconsin, } \\
\text { Wyoming, Pennsylvania, } \\
\text { Nebraska }\end{array}$ & 20 March & 20 May & 28 June \\
\hline
\end{tabular}

a Begin $=5 \%$ begin heading complete on tier and Feekes $=90$ to $95 \%$ Feekes 10.5 complete on tier.

${ }^{b}$ End of winter dormancy. Dates selected based on approximate timing for Feekes developmental stage 4
2005, 2006, 2007, and 2010 (Fig. 3). Because field-level wheat blast disease progress data were not available for general model validation, historical reports of regional outbreak and nonoutbreak years were used for model validation. The model validation tested whether the thresholds derived from the average history maps would correctly predict outbreak and nonoutbreak years. Model scores were extracted from 38 and 23 locations in Paraná and Rio Grande do Sul, respectively, where spring wheat is grown. Locations in Paraná included major wheat production municipalities historically prone to blast development. It was presumed that, during outbreak years, outbreaks occurred in all 38 locations in northern and western Parana and the opposite occurred for all nonoutbreak years. Locations in Rio Grande do Sul included major wheat production municipalities across the state historically unsuitable for blast development (EMATER 2013).

To estimate M. oryzae Triticum establishment and wheat blast outbreaks in the United States, we adapted the models according to agroecological conditions there (Fig. 1). Our climate suitability models targeted winter wheat production areas within the contiguous 48 U.S. states. Winter and spring wheat cultivars grown in the United States can be susceptible to various $M$. oryzae Triticum isolates (Cruz et al. 2012; Cruz et al. 2016) (G. Peterson, unpublished). However, based on the closely related $M$. oryzae Lolium pathotype behavior in the United States (Harmon and Latin 2005), low winter temperatures would likely preclude survival of M. oryzae Triticum in the northern United States where spring wheat is widely grown (Vocke and Ali 2013). Consequently, we extrapolated a threshold for M. oryzae Triticum inoculum overwintering from M. oryzae Lolium. The geographic range and transition zone of M. oryzae Lolium in the United States (Harmon and Latin 2003, 2005; Landschoot and Hoyland 1992; Latin and Harmon 2004; Pedersen et al. 2000; Schumann and Jackson 1999; Uddin et al. 1999; Wong 2006) were used to estimate a threshold for the number of days $\leq 0^{\circ} \mathrm{C}$ that could limit M. oryzae Triticum survival. Based on those data, U.S. maps of the average number of accumulated days with daily temperatures $\leq 0^{\circ} \mathrm{C}$ during the wheat-growing season were generated using 10 years of daily weather station data and a three-dimensional interpolation to a resolution of $10 \mathrm{~km}\left(100 \mathrm{~km}^{2}\right)$ (Magarey et al. 2011). A threshold was selected based on the approximate geographic range (northern boundary of transition zone) of gray leaf spot on perennial ryegrass in the United States (Harmon and Latin 2005, 2003; Landschoot and Hoyland 1992; Latin and Harmon 2004; Pedersen et al. 2000; Schumann and Jackson 1999; Uddin et al. 1999; Wong 2006), and this was used to generate a map showing the probability of years suitable for $M$. oryzae Triticum overwintering based on 10 years of weather data (Fig. 4).

A U.S. climate suitability map was created based on the components calibrated from model outputs in South America and the geographic range of $M$. oryzae Lolium. To account for the geographic variation in dates of winter wheat phenological stages, the United States was divided into three major groups or tiers (Table 1). Representative major wheat-producing states (USDA 2013) included Texas and Oklahoma (tier 1), Kansas (tier 2), and South Dakota and North Dakota (tier 3). We used dates for usual wheat active growth after winter dormancy, and dates for usual heading to delineate the tiers (Table 1) (Hall and Nleya 2012; Paulsen 1997; Royer 2010; Weisz 2013). Any counties in these tiers that grew winter wheat (USDA-NASS 2009) were selected and exported to GIS (ArcGIS Desktop Release 10.1; Environmental Systems Research Institute, Redlands, CA).

According to agroecological conditions in the United States, it was assumed that $M$. oryzae Triticum infections during the 60 days prior to heading generated the inoculum for head infections (Fig. 1). These 60 days correlated with Feekes developmental stage 4 in representative U.S. states for each tier (Hall and Nleya 2012; Large 1954; Paulsen 1997; Royer 2010; Weisz 2013). In order to identify areas of the United States where wheat was grown that would have the environmental conditions necessary to support establishment and outbreak, it was assumed that the pathogen was present. This was done because strains of $M$. oryzae Triticum have never been detected in the United States. 
Using the equations described above and the NAPPFAST system, maps were developed showing the probabilities of years suitable for establishment and outbreaks. These probability maps were created using the thresholds derived above. Given that estimated probability values of the climate suitability risk for M. oryzae Triticum establishment or wheat blast outbreak (i.e., the frequencies of suitable years) were discrete, a discrete distribution based on the proportion of each class was selected as a way of representing the climate suitability risk for $M$. oryzae Triticum establishment or wheat blast outbreak. Cell (pixel) counts were obtained from climate
PARANA
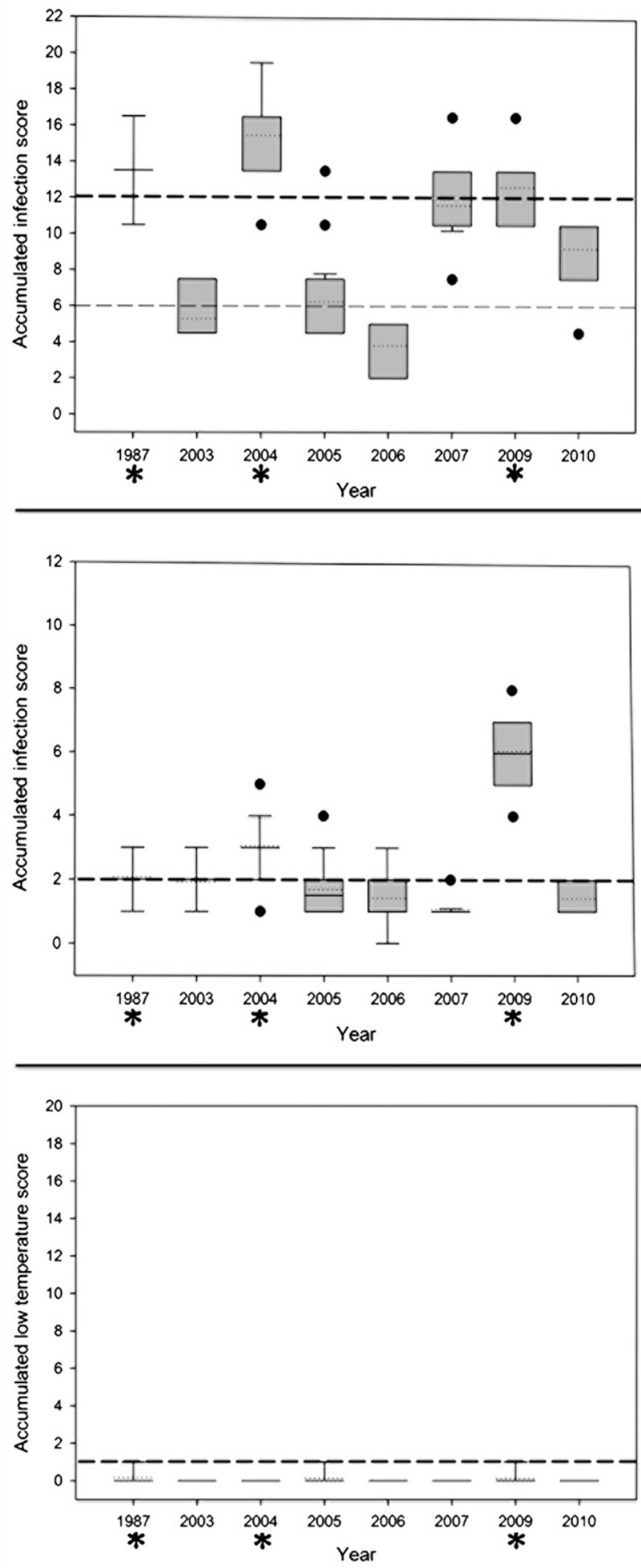

RIO GRANDE DO SUL

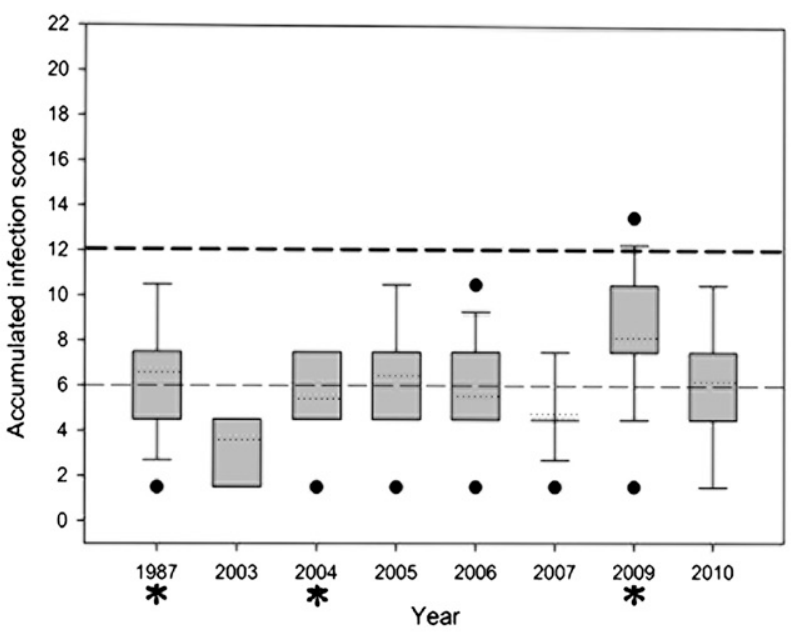

A

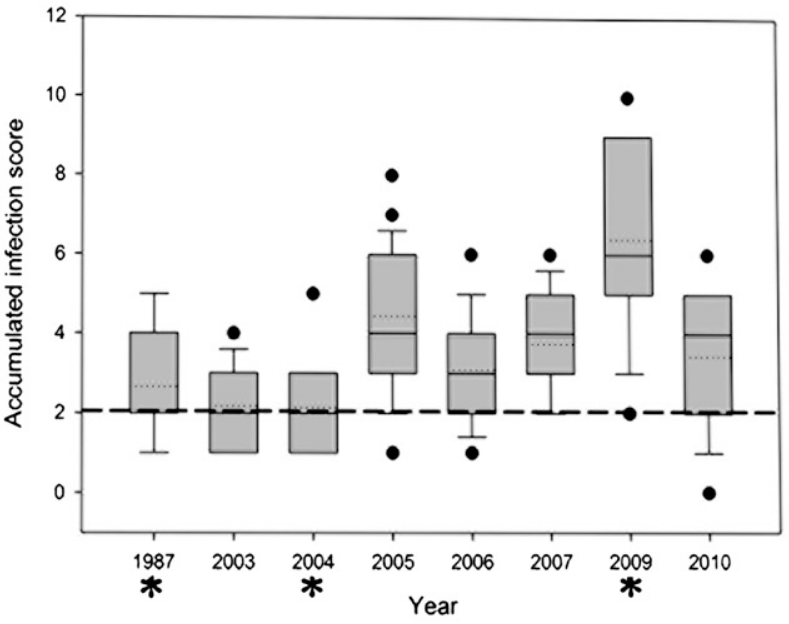

B

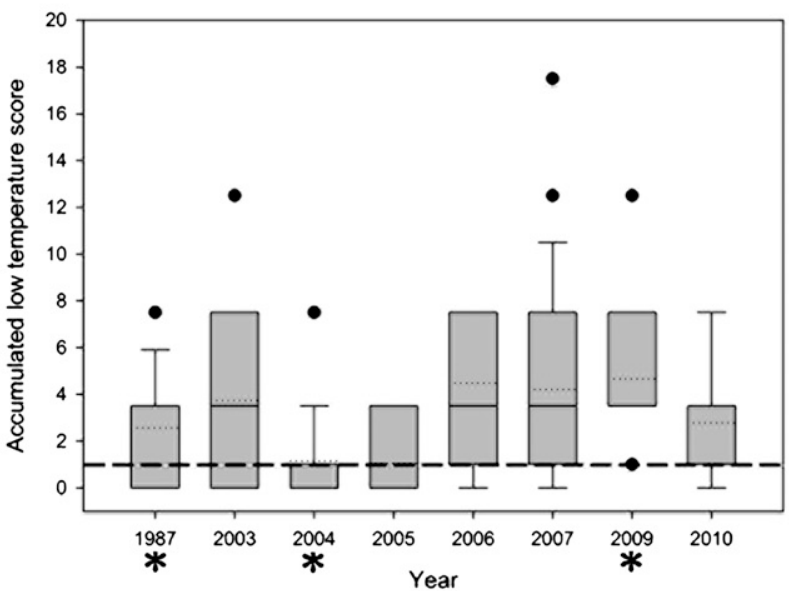

Fig. 3. Validation of model components using historical reports of outbreak $\left({ }^{*}\right)$ and nonoutbreak years for Paraná (38 locations historically prone to wheat blast) and Rio Grande Do Sul (23 locations historically unsuitable for wheat blast). The box plot shows 2, 25, 50, 75, and 98th percentiles of the accumulated events for A, inoculum buildup; B, infection at the heading stage; and $\mathbf{C}$, overwintering survival. 
suitability maps from the three tiers (data not shown). Cell counts only included data from final climate suitability maps that considered winter wheat presence.

\section{Results}

Validation of model thresholds. The model thresholds were estimated from average history maps for each component. Based on extrapolations from Rio Grande do Sul (Fig. 2), an infection score threshold for $M$. oryzae Triticum infection prior to heading (i.e., inoculum buildup) of $\geq 6$ was necessary for $M$. oryzae Triticum establishment (Fig. 2A-RS). Based on extrapolations from northern and western Paraná, an infection score threshold of $\geq 12$ was necessary for wheat blast outbreak (Fig. 2A-PR). Based on Paraná and Rio Grande do Sul, an infection score threshold for M. oryzae Triticum infection at the heading stage of $\geq 2$ was selected for both $M$. oryzae Triticum establishment and wheat blast outbreak (Fig. 2B). A surrogate threshold of $\geq 1$ day with temperatures $\leq 0^{\circ} \mathrm{C}$ was selected for M. oryzae Triticum overwintering in Brazil (Fig. 2C).

The reliability of the thresholds was tested for each component and state against historical observations of outbreak and nonoutbreak years. The model score for each location and each year was extracted from the predictive maps (Supplementary Fig. S1) and displayed against the threshold values for each component (Fig. 3). For infection prior to heading in Paraná (Fig. 3A.), the mean accumulated events for inoculum buildup were above the outbreak threshold value of 12 for all outbreak years; for all nonoutbreak years, those accumulated events were below 12 . The predictive maps for outbreak years 1987, 2004, and 2009 were consistent with historical outbreak development in northern and western Paraná. In Rio Grande do Sul, the mean accumulated events for inoculum buildup were below the outbreak threshold value of 12 for all outbreak and nonoutbreak years. Instead, accumulated infection values were consistently close to 6 , the threshold for establishment. In Paraná, the mean accumulated infection events at the heading stage were above the outbreak threshold value of 2 for all outbreak years; for all nonoutbreak years, those accumulated events were below 2. In Rio Grande do Sul, the mean accumulated infection events at heading were above the outbreak threshold value for all outbreak and nonoutbreak years. In Paraná, the mean accumulated events for temperatures $\leq 0^{\circ} \mathrm{C}$ was approximately zero across all years whereas, in Rio Grande do Sul, it was greater than one across all years. During outbreak years, Rio Grande do Sul showed lower infection events prior to heading and higher accumulated days with temperatures less than $0^{\circ} \mathrm{C}$ than in northern and western Paraná.

A second test of the thresholds was to create probability maps for Rio Grande Do Sul and Parana (Supplementary Fig. S2). When the multiplication rule (Vose 2008) was implemented for the three components and according to appropriate thresholds for each component, the model predicted outbreaks in Paraná with a probability between 0.2 to 0.7 or less, typically 0.4 ( 2 to 7 years or less out of 10 were suitable, with an average of 4 years out of 10). The model predicted outbreaks in Rio Grande do Sul with a probability of 0.1 or less.

U.S. risk maps. The probability of $M$. oryzae Triticum establishment and wheat blast outbreak in the United States varied dramatically by location. For approximately $60 \%$ of the winter wheat production areas within the contiguous 48 U.S. states, the probability of $M$. oryzae Triticum establishment was zero (Fig. 5A). In the remaining $40 \%$ of the winter wheat production areas, climatic conditions allowed $M$. oryzae Triticum establishment in a range from 1 in 10 years $(P=0.1)$ to 9 in 10 years $(P=0.9)$; in any given probability $(P)$ category, 0.08 or less of the winter wheat production area was at risk. Areas with climatic conditions suitable for $M$. oryzae Triticum establishment $(P \geq 0.1)$ were located in the following states: Alabama, Arkansas, Delaware, Florida, Georgia, Illinois, Indiana, Iowa, Kansas, Kentucky, Louisiana, Maryland, Michigan, Mississippi, Missouri, Nebraska, New Jersey, North Carolina, Ohio, Oklahoma, Pennsylvania, South Carolina, Tennessee, Texas, Virginia, and West Virginia (Fig. 5A). For approximately $75 \%$ of the winter wheat production areas in the contiguous 48 U.S. states, the probability of wheat blast outbreak was zero (Fig. 5B). In the remaining $25 \%$, climatic conditions suitable for wheat blast outbreak occurred from 1 in 10 years $(P=0.1)$ to 8 in 10 years $(P=$ $0.8)$. Areas with climatic conditions suitable for wheat blast

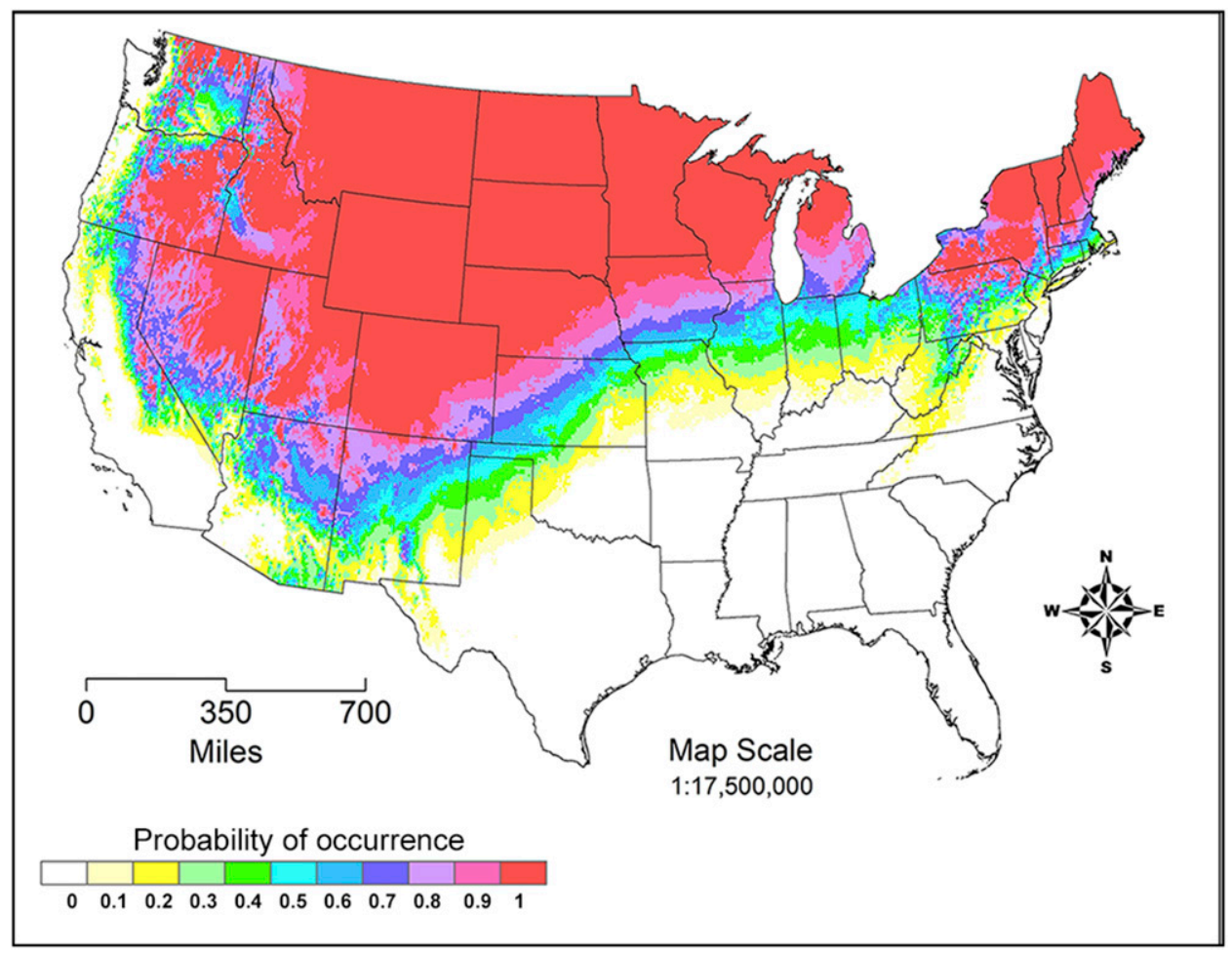

Fig. 4. Probability of occurrence of 105 or more freezing days in a 10-year period based on weather data from the NAPPFAST North American daily station dataset. Magnaporthe oryzae Triticum is expected not to survive in the red area if it follows the epidemiology of the M. oryzae Lolium pathotype. Likewise, M. oryzae Triticum overwinter survival will not likely be limited in the white area, and may or may not be limited in some years in the transition area between red and white. 
outbreak $(P \geq 0.1)$ were located in the following states: Alabama, Arkansas, Florida, Georgia, Illinois, Indiana, Kansas, Kentucky, Louisiana, Mississippi, Missouri, North Carolina, Ohio, Oklahoma, Pennsylvania, South Carolina, Tennessee, Texas, Virginia, and West Virginia (Fig. 5B). However, only in Louisiana, Mississippi, and Florida was the probability of years suitable for outbreaks $P \geq 0.7$.

\section{Discussion}

Our validation of thresholds for each model component using locations in Brazil (Fig. 3) showed a clear distinction between locations in northern or western Paraná and Rio Grande do Sul. Historically, wheat blast outbreaks have sporadically occurred and caused the greatest yield and economic losses in northern and western Paraná (Alves and Fernandes 2006; Antunes da Cruz 2008; Igarashi 1988; Lima 2004). Our results showed that, for locations in northern and western Paraná, no limitation for inoculum buildup, infection at heading, and inoculum overwintering survival existed during outbreak years. The opposite occurred during nonoutbreak years, when a combination of limitations for inoculum buildup or infection during heading existed. For locations in Rio Grande do Sul, limitations for inoculum buildup and inoculum overwintering survival existed for all years; however, no limitation for infection at the heading stage existed. With this level of consistency, we concluded that the thresholds for each component were precise in predicting conditions suitable for M. oryzae Triticum establishment across locations in Rio
Grande do Sul and blast outbreaks across locations in northern and western Paraná.

We acknowledge that caution should be taken when using the proposed overwintering component in Brazil, due to the lack of direct M. oryzae Triticum data to prove cause and effect with respect to sensitivity to freezing days and freezing temperatures in Rio Grande do Sul. Nevertheless, it has been reported that, in Brazil, wheat blast outbreaks occur with higher frequency at warmer latitudes (i.e., less than $24^{\circ}$ South) (Alves and Fernandes 2006). Our results suggest that there is a transition zone where temperatures during winters can fall below $0{ }^{\circ} \mathrm{C}$. These temperatures could well be associated with the absence of wheat blast outbreaks in Rio Grande do Sul. In order to corroborate these findings, it will be important to analyze climatic data and to more closely monitor and compare $M$. oryzae Triticum populations from Paraná and Rio Grande do Sul. In addition, a direct extrapolation of the models used to estimate M. oryzae Triticum establishment or wheat blast outbreak from Brazil to the United States was not possible due to the major agroecosystem differences between these two countries. The model components were selected, calibrated, and validated on an agroecosystem corresponding to a single plant hardiness zone in the states of Paraná and Rio Grande do Sul, Brazil (Del Ponte et al. 2015; Kochhann 1987; Magarey et al. 2008). However, the contiguous 48 U.S. states encompassed a larger and more complex agroecosystem, with nine plant hardiness zones (Magarey et al. 2008), on which various classes of wheat are grown based on climate and regional differences. As discussed above, our climate suitability

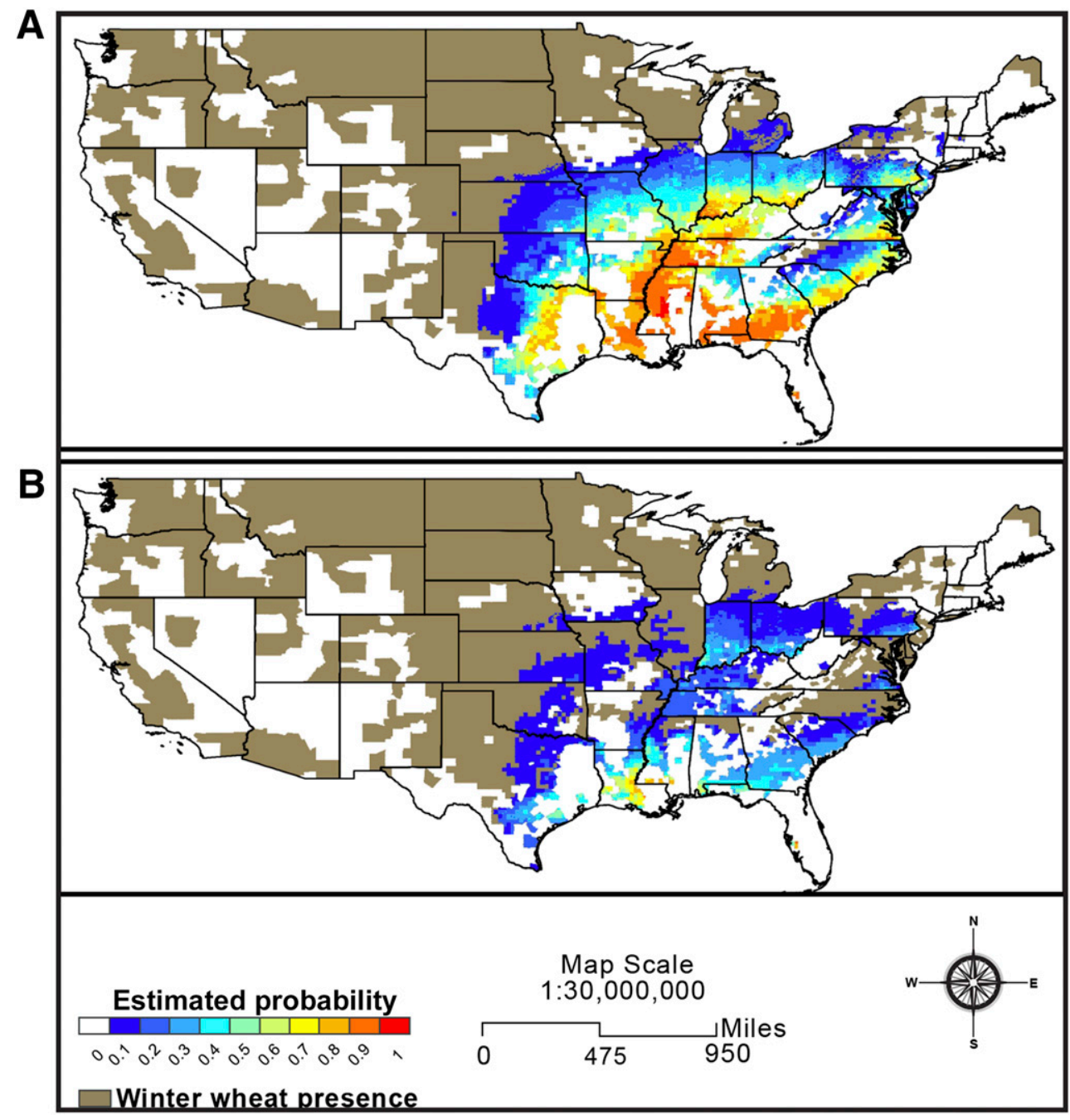

Fig. 5. Climate suitability risk maps showing the estimated probabilities of Magnaporthe oryzae Triticum A, establishment and B, wheat blast outbreak in the contiguous 48 U.S. states based on 10 years of National Centers for Environmental Prediction Climate Forecast System Reanalysis climate data. Colored areas overlay a brown color that indicates presence of wheat. White areas correspond to areas where wheat is not grown. 
risk models only targeted winter wheat production areas in the United States in contrast to the spring wheat areas commercially grown in Brazil. Thus, a direct extrapolation of all components and thresholds for each component would have been unreasonable.

According to our results, the potential distribution of $M$. oryzae Triticum and the wheat blast disease in the United States are likely to be limited by specific temperatures and precipitation requirements for infection and extreme low temperatures that might limit M. oryzae Triticum overwintering survival. Based on the closely related M. oryzae Lolium behavior in the United States, low winter temperatures would likely preclude survival of $M$. oryzae Triticum in the northern United States (Fig. 4). Our climate-based mechanistic approach predicted that most of the winter wheat areas suitable for M. oryzae Triticum establishment or wheat blast outbreak were in the southeastern United States. Rice blast is endemic in southern rice-producing states and has been reported in Arkansas, Louisiana, Texas, Mississippi, Florida, and South Carolina (Greer and Webster 2001; Marchetti et al. 1976; Moldenhauer et al. 2005). Although the disease does not occur every year, a summary of historical extension reports indicates that rice blast reaches damaging levels in unsprayed rice plots $25 \%$ and $13 \%$ of years for Arkansas, and Louisiana respectively (E. DeWolf, personal communication). The riceproducing regions of southeastern Texas have also experienced multiple outbreaks of rice blast in the last 5 years. This corroborates our findings for southern states, where we predict wheat blast outbreaks to be frequent. In addition, winter wheat areas predicted as suitable for M. oryzae Triticum establishment or wheat blast outbreak were also identified in restricted areas in the Great Plains, Midwest, and Northeast of the United States (Fig. 5). With the threshold levels selected, we conclude that the climate within the contiguous 48 U.S. states was more suitable for establishment of $M$. oryzae Triticum populations than to support wheat blast outbreaks.

Our climate-based mechanistic approach should be of value to the development of more sophisticated models. Modelers should consider that, in this study, the generic infection model template of NAPPFAST used daily weather data (Magarey et al. 2007). These data were processed into infection potential and the built-in accumulate function calculated the total number of times an event (e.g., infection) occurred. Nonetheless, the major limitation of using daily data as opposed to hourly or subhourly data is that $M$. oryzae infection processes occur over a smaller temporal scale than a day (Howard et al. 1991). The generic infection model might not have examined the influence of the duration and timing of wetness interruptions. A simulation model based on hourly weather inputs (Bregaglio et al. 2013; Kang et al. 2010) may provide a better estimate for disease development. Important components of such an advanced model could include inoculum buildup as influenced by temperature and humidity, host phenological susceptibility as estimated from observations or a degree-day model, and the number of infection periods during heading. Other factors such as host resistance and inoculum buildup in the previous season may be critical. Validation of a model based on hourly weather data might be hampered by the lack of detailed weekly observations of disease progress. Therefore, additional studies based on weekly observations of leaf and head blast incidence and severity from planting to heading will be required during outbreak and nonoutbreak years. If such a model could be built, there is potential to include it in services that provide pest forecasts to growers such as the Integrated Pest Information Platform (Isard et al. 2015).

The accuracy and predictive ability of our models should be improved and the uncertainty resulting from insufficient information reduced as we gain a more complete understanding of the biology of M. oryzae Triticum and the epidemiology of the wheat blast disease. The results reported in this article could be used to prioritize research efforts regarding the biology of M. oryzae Triticum and the epidemiology of wheat blast. Additionally, the climate suitability risk maps developed in this study might be useful for designing future M. oryzae Triticum surveillance systems. Once the most likely routes for M. oryzae Triticum entry into the United States are defined, the probability of favorable years for establishment and outbreak obtained in this study will be a critical component. Moreover, a pathway risk assessment could be of benefit for phytosanitary purposes to help identify areas with imminent risk of $M$. oryzae Triticum establishment or wheat blast outbreak in the United States. M. oryzae Triticum is a potential threat to U.S. wheat production. M. oryzae Triticum is a seedborne pathogen (Goulart and Paiva 1990; Goulart and Paiva 1991; Goulart and Paiva 1993) and, consequently, contaminated seed or grain can be the vehicle of its introduction to nonendemic countries. For example, a consortium of livestock producers on the East Coast of the United States imported 126,000 and 268,000 t of Brazilian wheat grain during 2009 and 2010, respectively (USDA 2013), indicating that a pathway for introduction existed between the two countries.

\section{Acknowledgments}

The project has been funded by Agriculture and Food Research Initiative Competitive Grants 2009-55605-05201 and 2013-68004-20378 from the United States Department of Agriculture National Institute of Food and Agriculture (USDANIFA). Contribution number 15-438-J from the Kansas Agricultural Experiment Station. NAPPFAST was formerly supported by the Animal and Plant Health Inspection Service Plant Protection and Quarantine. The work was also supported by the USDA-NIFA AFRI Competitive Grants Program Food Security Challenge Area grant 2015-68004-23179.

\section{Literature Cited}

Alves, K., and Fernandes, J. 2006. Influência da Temperatura e da Umidade Relativa do Ar na Esporulação de Magnaporthe grisea em Trigo. Fitopatol. Bras. 31:579-584.

Anderson, A., Henry, B., and Tullis, E. 1947. Factors affecting infectivity, spread and persistence of Pyricularia oryzae Cav. Phytopathology 37:94-110.

Antunes, J. 2014. Brusone do trigo é identificada em lavouras no Noroeste do RS. Online publication. Embrapa, Brazilian Agricultural Research Corporation. https://www.embrapa.br/en/busca-de-noticias/-/noticia/2103461/brusone-do-trigoe-identificada-em-lavouras-no-noroeste-do-rs

Antunes da Cruz, M. 2008. Caracterização do padrão molecular e de virulência de isolados de Pyricularia grisea do trigo. Dissertation, Universidade de Passo Fundo, Brazil.

Aucique Perez, C., Rodrigues, F., Moreira, W., and DaMatta, F. 2014. Leaf gas exchange and chlorophyll $a$ fluorescence in wheat plants supplied with silicon and infected with Pyricularia oryzae. Phytopathology 104:143-149.

Bregaglio, S., Donatelli, M., and Confalonieri, R. 2013. Fungal infections of rice wheat and grape in Europe in 2030-2050. Agron. Sustain. Dev. 33:767-776.

CONAB. 2015. TRIGO_BRASIL: Série Histórica de Produtividade Safras 1976 a 2015. Online publication. Companhia Nacional de Abastecimento (CONAB). http://www.conab.gov.br/OlalaCMS/uploads/arquivos/16_01_12_10_08_20_ trigoseriehist.xls

Cruz, C. D., Bockus, W. W., Stack, J. P., Tang, X., Valent, B., Pedley, K. F., and Peterson, G. L. 2012. Preliminary assessment of resistance among U.S. wheat cultivars to the Triticum pathotype of Magnaporthe oryzae. Plant Dis. 96: 1501-1505.

Cruz, C. D., Kiyuna, J., Bockus, W. W., Todd, T. C., Stack, J. P., and Valent, B. 2015. Magnaporthe oryzae conidia on basal wheat leaves as a potential source of wheat blast inoculum. Plant Pathol. 64:1491-1498.

Cruz, C. D., Peterson, G. L., Bockus, W. W., Kankanala, P., Dubcovsky, J., Jordan, K. W., Akhunov, E., Chumley, F., Baldelomar, F. D., and Valent, B. 2016. The 2NS translocation from Aegilops ventricosa confers resistance to the Triticum Pathotype of Magnaporthe oryzae. Crop Sci. 56:990-1000.

de Andrade Cardoso, C., Reis, E., and Moreira, E. 2008. Development of a warning system for wheat blast caused by Pyricularia grisea. Summa Phytopathol. 34:216-221.

Del Ponte, E. M., Spolti, P., Ward, T. J., Gomes, L. B., Nicolli, C. P., Kuhnem, P. R., Silva, C. N., and Tessmann, D. J. 2015. Regional and field-specific factors affect the composition of Fusarium head blight pathogens in subtropical no-till wheat agroecosystem of Brazil. Phytopathology 105:246-254.

EMATER. 2013. Trigo-Area Plantada (ha). Online publication. Emater/RS http://www.emater.tche.br/site/arquivos_pdf/serie/serie_5120130327.pdf

Farman, M. 2002. Pyricularia grisea isolates causing gray leaf spot on perennial ryegrass (Lolium perenne) in the United States: Relationship to P. grisea isolates from other host plants. Phytopathology 92:245-254.

Fowler, G., and Takeuchi, Y. 2012. Mapping, Climate and Geographic Information for Risk Analysis. Pages 151-163 in: Plant Pest Risk Analysis: Concepts and Applications. C. Devorshak, ed. CAB International, Oxford.

Goulart, A., and Paiva, F. 1990. Transmissão de Pyricularia oryzae através de sementes de trigo (Triticum aestivum L.). Fitopatol. Bras. 15:359-362.

Goulart, A. and Paiva, F. 1991. Controle da Pyricularia oryzae e Helminthosporium sativum pelo tratamento de sementes de trigo com fungicidas. Pesquisa Agropecuária Brasileira 26:1983-1988.

Goulart, A., and Paiva, F. 1993. Sobrevivência de Pyricularia oryzae Cav. em sementes de trigo (Triticum aestivum L.) armazenadas em diferentes ambientes. Rev. Brasil. Sementes 15:153-156. 
Greer, C. A., and Webster, R. K. 2001. Occurrence, distribution, epidemiology, cultivar reaction, and management of rice blast disease in California. Plant Dis. 85:1096-1102.

Hall, R., and Nleya, T. 2012. Winter and spring wheat growing stages. Pages 23-32 in: iGrow Wheat-Best Management Practices for Wheat Production. D. Clay, C. Carlson, and K. Dalsted, eds. South Dakota State University, Brookings.

Harmon, P., and Latin, R. 2003. Gray leaf spot of perennial ryegrass. Online publication. Plant Health Prog. doi:10.1094/PHP-2003-1223-01-DG

Harmon, P., and Latin, R. 2005. Winter survival of the perennial ryegrass pathogen Magnaporthe oryzae in north central Indiana. Plant Dis. 89:412418 .

Howard, R., Ferrari, M., Roach, D., and Money, N. 1991. Penetration of hard substrates by a fungus employing enormous turgor pressures. Proc. Natl. Acad. Sci. USA 88:11281-11284.

Igarashi, S. 1988. Brusone no trigo-Histórico e distribuição geográfica no Paraná. Page 157 in: Reunião nacional de pesquisa de trigo, 15. Embrapa, Passo Fundo, Brazil.

Igarashi, S. 1990. Update on wheat blast (Pyricularia oryzae) in Brazil. Pages 480-483 in: Proc. Int. Conf. Wheat Nontraditional Warm Areas, Mexico DF. D. Saunders, ed

Igarashi, S., Utimada, C., Igarashi, L., Kazuma, A., and Lopes, R. 1986. Pyricularia sp. em trigo. I. Ocorrência de Pyricularia sp. no Estado do Paranà. Fitopatol. Bras. 11:351-352.

IPPC. 2008. ISPM No. 5: Glossary of phytosanitary terms. International standards for phytosanitary measures. Online publication. International Plant Protection Convention (IPPC). http://archives.eppo.int/WORLDWIDE/1999/glossary_99. htm

Isard, S. A., Russo, J. M., Magarey, R. D., Golod, J., and VanKirk, J. R. 2015. Integrated Pest Information Platform for Extension and Education (iPiPE): Progress through sharing. J. Integr. Pest Manage. 6:15.

Junges, A., and Fontana, D. 2009. Quebras de safra de trigo no estado do Rio Grande do Sul: Um estudo de caso. In: XVI Congr. Bras. Agrometeorol. Belo Horizonte, Brazil

Kang, W., Hong, S., Hang, Y., Kim, K., Kim, S., and Park, E. 2010. A Web-based Information System for Plant Disease Forecast Based on Weather Data at High Spatial Resolution. Plant Pathol. J. 26:37-48.

Kapoor, A., and Singh, B. 1977. Overwintering of Pyricularia oryzae in Himachal Pradesh. Indian Phytopathol. 30:213-216.

Kochhann, R. 1987. Fertilizer requirements and management issues for acid soils in nonirrigated areas. Pages 220-222 in: Wheat Production Constraints in Tropical Environments. A. Klatt, ed. UNDP/CIMMYT, Mexico DF.

Landschoot, P., and Hoyland, B. 1992. Gray leaf spot of perennial ryegrass turf in Pennsylvania. Plant Dis. 76:1280-1282.

Large, E. C. 1954. Growth stages in cereals illustration of the Feekes scale. Plant Pathol. 3:128-129.

Latin, R., and Harmon, P. 2004. Managing gray leaf spot in the Midwest. Golf Course Manage. 72:89-92.

Lima, M. 2004. Giberela ou brusone? Orientações para a identificação correta dessas enfermidades em trigo e em cevada. Online publication. Embrapa Trigo Documentos. http://www.cnpt.embrapa.br/biblio/do/p do40.pdf

Magarey, R. D., Borchert, D. M., and Schlegel, J. W. 2008. Global plant hardiness zones for phytosanitary risk analysis. Sci. Agric. 65:54-59.

Magarey, R. D., Borchert, D. M., Engle, J. S., Colunga-Garcia, M., Koch, F. H., and Yemshanov, D. 2011. Risk maps for targeting exotic plant pest detection programs in the United States. Bull. OEPP/EPPO Bull. 41:4656.

Magarey, R. D., Borchert, D. M., Fowler, G. A., and Hong, S. C. 2015. The NCSU/APHIS Plant Pest Forecasting System (NAPPFAST). Pages 82-96 in: Pest Risk Modeling and Mapping for Invasive Alien Species. R. Venette, ed. CABI, Wallingford, UK.

Magarey, R. D., Fowler, G. A., Borchert, D. M., Sutton, T. B., Colunga-Garcia, M., and Simpson, J. A. 2007. NAPPFAST: An internet system for the weather-based mapping of plant pathogens. Plant Dis. 91:336-345.

Magarey, R. D., and Sutton, T. B. 2007. How to create and deploy infection models for plant pathogens. Pages 3-25 in: Integrated Management of Plant Pests and Diseases. Vol. I: General Concepts in Integrated Pest and Disease Management. A. Ciancio and K. G. Mukerji, eds. Springer, New York.

Magarey, R. D., Sutton, T. B., and Thayer, C. L. 2005. A simple generic infection model for foliar fungal plant pathogens. Phytopathology 95:92-100.
Marchetti, M., Rush, M., and Hunter, W. 1976. Current status of rice blast in the Southern United States. Plant Dis Rep 60:721-725.

McMichael, A., Campbell-Lendrum, D., Corvalán, C., Ebi, K., Githeko, A. Scheraga, J., and Woodward, A. 2003. Climate Change and Human Health-Risk and Responses. World Health Organization, Geneva, Switzerland.

Moldenhauer, K. A., Gibbons, J. W., Lee, F. N., Wilson, C. E., Bernhardt, J. L., Anders, M. A., Cartwright, R. D., Norman, R. J., Bryant, R., Rutger, J. N., Blocker, M. M., Boyett, V. A., Griffith, A., Bulloch, J. M., and Taylor, K. 2005. In: Research Series 540: B. R. Wells Rice Research Series 2005. Arkansas Agricultural Experiment Station, Fayetteville, AR.

Moss, M., and Trevathan, L. 1987. Environmental Conditions Conducive to Infection of Ryegrass by Pyricularia grisea. Phytopathology 77:863-866.

Paulsen, G. 1997. Growth and development. Pages 2-11 in: Wheat Production Handbook. Publication C-529. Kansas State University Cooperative Extension Service, Manhattan, KS

Pedersen, D. K., Kane, R. T., and Wilkinson, H. T. 2000. First report of gray leaf spot caused by Pyricularia grisea on Lolium perenne in Illinois. Plant Dis. 84: 1151.

Rios, A., Debona, D., Duarte, H., and Rodrigues, F. 2013. Development and validation of a standard area diagram set to assess blast severity on wheat leaves. Eur. J. Plant Pathol. 136:603-611.

Royer, T., ed. 2010. Pest Management Strategic Plan for Winter Wheat in the Southern Great Plains. USD Grazinglands Research Center, El Reno, OK

Saha, S., Nadiga, S., Thiaw, C., Wang, J., Wang, W., Zhang, Q., Van Den Dool, H., Pan, H. L., Moorthi, S., Behringer, D., Stokes, D., Peña, M., Lord, S., White, G., Ebisuzaki, W., Peng, P., and Xie, P. 2006. The NCEP climate forecast system. J. Clim. 19:3483-3517.

Schumann, G., and Jackson, N. 1999. First report of gray leaf spot (Pyricularia grisea) on perennial ryegrass (Lolium perenne) in New England. Plant Dis. $83: 1073$

Torres, G., Santana, F., Fernandes, J., and Só e Silva, M. 2009. Doenças da espiga causam perda de rendimento em trigo nos estados do Paraná, São Paulo e Mato Grosso do Sul, em 2009. Embrapa Trigo. Available online at: http://www.cnpt. embrapa.br/biblio/co/p_co255.htm

Uddin, W., Serlemitsos, K., and Viji, G. 2003a. A temperature and leaf wetness duration-based model for prediction of gray leaf spot of perennial ryegrass turf. Phytopathology 93:336-343.

Uddin, W., Soika, M. D., Moorman, F. E., and Viji, G. 1999. A serious outbreak of blast disease (gray leaf spot) of perennial ryegrass in golf course fairways in Pennsylvania. Plant Dis. 83:783.

Uddin, W., Viji, G., and Vincelli, P. 2003b. Gray leaf spot (blast) of perennial ryegrass turf-An emerging problem for the turfgrass industry. Plant Dis. 87: 880-889.

USDA. 2013. United States: Winter Wheat. Online publication. United States Department of Agriculture Agricultural Weather Assessments. http://www.usda.gov/oce/ weather/pubs/Other/MWCACP/Graphs/USA/US WheatWinter 2010 to 2014.pdf

USDA-NASS. 2009. 2007 Census of Agriculture. Online publication. United States Department of Agriculture National Agricultural Statistics Service. https://www.agcensus.usda.gov/Publications/2007/Full_Report/index.asp

Venette, R. C., Kriticos, D. J., Magarey, R. D., Koch, F. H., Baker, R. H. A., Worner, S. P., Raboteaux, G., Nadilia, N., McKenney, D. W., Dobesberger, E. J., Yemshanov, D., De Barro, P. J., Hutchison, W. D., Fowler, G., Kalaris, T. M., and Pedlar, J. 2010. Pest risk maps for invasive alien species: A roadmap for improvement. Bioscience 60:349-362.

Vocke, G., and Ali, M. 2013. Wheat Production Practices, Costs, and Yields: Variations Across Regions, EIB-116. U.S. Department of Agriculture, Economic Research Service, Washington, DC.

Vose, D. 2008. Risk Analysis: A Quantitative Guide, 3rd ed. John Wiley \& Sons, Ltd., West Sussex, England.

Weisz, R. 2013. Small grain growth and development. Pages 1-4 in: Small grain production guide. R. Weisz, ed. North Carolina Cooperative Extension Service, Raleigh.

Wong, F. 2006. Gray leaf spot in the West: A new disease of perennial ryegrass and kikuyugrass has become established in California and Nevada. Golf Course Manage. 74:97-101.

Yang, X. B. 2003. Risk assessment: Concepts, development, and future opportunities. Online publication. Plant Health Prog. doi:10.1094/PHP2003-1113-02-RV

Yang, X. B. 2006. Framework development in plant disease risk assessment and its application. Eur. J. Plant Pathol. 115:25-34. 